\title{
KANT ON RELIGIOUS FEELING - AN EXTRAPOLATION
}

\author{
BIRGIT RECKI
}

Universität Hamburg

\begin{abstract}
The religious feeling considered in this paper is the feeling of awe that can be construed in the extrapolation of the feeling of respect for the law. The latter itself can be better understood in analogy to the feeling of the sublime. Hence the thesis of my interpretation and extrapolation is: a characterization of the religious feeling in Kant's critiques of reason and their analyses of feelings is possible. It has to be understood in analogy to the feeling of respect for the law and thus to the feeling of the sublime. The religious feeling would, as certain formulations suggest, refer to awe of the inconceivable size of God. The religious feeling of awe would also be a feeling caused by reason - an instance of a judgement-based feeling. The respective judgement is a reflexive judgement, an achievement of the reflecting faculty of judgement. The religious feeling would resemble Schleiermacher's 'plain feeling of dependence', but given the analogy with the dialectics of the sublime, it would also include the complementary component of self-elevation.
\end{abstract}

In the Observations on the Feeling of the Beautiful and Sublime (1764), Kant already has a concept of moral feelings. Much later, in the Metaphysics of Moral's 'Doctrine of Virtue' (1797), he subsumes them under the heading of an 'aesthetics of morality.' At this point, Kant has discarded feelings as the principle of morality and, at the same time, systematically construed the moral feeling - a remarkable feat in more than one respect. The moral feeling is, according to Kant, necessary as

\footnotetext{
${ }^{1}$ Immanuel Kant, Metaphysik der Sitten (Tugendlehre), AA Vol. VI (henceforth: MM), p. 406. In English: The Metaphysical Elements of Ethics (Doctrine of Virtue), trans. by Thomas Kingsmill Abbott. See Birgit Recki, Ästhetik der Sitten. Die Affinität von ästhetischem Gefühl und praktischer Vernunft bei Kant (Frankfurt am Main: Vittorio Klostermann, 2001). Translator's note: Unless indicated otherwise, translations are my own. Page numbers refer to the German edition.
} 
an 'incentive' ('Triebfeder') for acting in accordance with rational insights, and it has to measure up against the criteria of a critical transcendental philosophy. This feeling is respect for the law, which is caused by reason and is the only feeling that may play any role in a morality based on pure reason. ${ }^{2}$ In the Critique of Judgement (1790), Kant also offers a theory of aesthetic feelings: in aesthetic judgements, the subject articulates 'the feeling which [it] has of itself' in the face of the beautiful ${ }^{3}$ that arises from the free play of reflection between imagination and intellect. ${ }^{4}$ It also articulates a 'disposition of the soul' ${ }^{5}$ that arises in the 'conflict' between imagination and intellect when facing the sublime: 'a feeling of our possessing a pure and self-sufficient reason' ${ }^{6}$

It does not seem as if Kant had any concept, or even a theory, of religious feelings. The work where one might suspect to find such a theory - Religion within the Boundaries of Mere Reason (1973) - shows an author who makes every attempt at exposing the meaning and importance of faith as an epistemic attitude for morality, and the rationally reconstructable function of Christian faith. Kant wants to employ the contents of faith only with regard to this function. Kant's Religion within the Boundaries can be understood as the continuation of his critical ethics by other means. This corresponds with his characterization in the theological speculation of the third critique: 'Religion [...] i.e. morals in reference to God as legislator' (CJ \$ 89). Moral philosophy is continued by other means, i.e. by expanding the concept of morality by the hitherto undiscussed dimension of institutional support (a church) and orientation based on tradition (revelation). In the analyses of Religion within the Boundaries, feelings play no central role. When Kant addresses feelings here, they concern the discussion of enthusiastic superstition or insanity $^{7}$ (REL, p. 194), or the discussion of an intuitive understanding

${ }^{2}$ Immanuel Kant, Kritik der praktischen Vernunft, (1788), AA Vol. V (henceforth: CpR): Von den Triebfedern der reinen praktischen Vernunft. In English: Critique of Practical Reason: Of the Motives of Pure Practical Reason, trans. by Thomas Kingsmill Abbott.

${ }^{3}$ Immanuel Kant, Kritik der Urteilskraft (1790), AA Vol. V (henceforth: CJ), §1. In English: Critique of Judgement, trans. by James Creed Meredith.

${ }^{4} \mathrm{CJ}, \$ 216 \mathrm{ff}$.

${ }^{5} \mathrm{CJ}, \S 25$.

${ }^{6} \mathrm{CJ}, \S 27$.

${ }^{7}$ Immanuel Kant, Die Religion innerhalb der Grenzen der bloßen Vernunft (1793), AA Vol. VI (henceforth: REL), pp. 174f. In English: Religion within the Boundaries of Mere Reason, trans. by George Di Giovanni. 
of the Bible (REL, pp. 113f.). In both cases, Kant rejects any relevance of feelings. There is no mention of religious feelings in an emphatic understanding and affirmative evaluation.

However, could it not easily be otherwise? We may note that, after the analyses of moral and aesthetic feelings - where Kant insists that they are caused by reflection - the Kantian critique of reason does have the potential for a conceptual characterization of a religious feeling. The question is merely where it can be found and how it is to be construed.

I.

'1) What can I know? 2) What ought I to do? 3) What may I hope?', Kant asks in his 1781 Critique of Pure Reason. In the 1800 Logic, he repeats these three questions and emphasizes that they determine the extent of the greater question: '4) What is the human being?' One could rightly say that the three questions constitute the systematic layout of the Kantian critique of reason: a critique of cognition, a critique of (moral) action, and a critique of speculative reflection about the state of the world as the totality of cognition and action. Kant puts it slightly differently. Although this does not mean that my assignment of the three questions to the three critiques (Critique of Pure Reason, Critique of Practical Reason, Critique of Judgement) needs to be suspended, we should present his own explanation: 'The first question is answered by metaphysics, the second by morals, the third by religion and the fourth by anthropology.' ${ }^{8}$ Concerning the question of Kant's concept of religious feeling, the following is particularly interesting: the question what may I hope is answered by religion. In the critique of reason's architecture, religion marks the place of hope as a speculative reflection about the state of the world in which the subject may feel at home. However, this does not mean that the answer to this question could only be expected from Religion within the Boundaries, because this is not the first of Kant's works addressing the issue of religion. After all, religion is also a topic of the first critique when Kant is discussing the rational justification of belief. The doctrine of the highest good developed in the Critique of Practical Reason and its continuation in positing two necessary objects of belief - God and the immortality of the soul - lead Kant to expose

8 Immanuel Kant, Logik (1800), AA Bd. IX, p. 25. In English: Logic (London: Longmans Green, 1885), trans. by Thomas Kingsmill Abbott. 
what he calls a practical rational faith. ${ }^{9}$ The systematic aim of the third critique is not solely to guarantee the metaphysical frame for this practical rational faith by speculating about a purposeful nature. It also ends with an appeal in the trial against proofs of God - the ethico-theological proof for God. ${ }^{10}$

Would it not be obvious to locate the feeling in hope, which has been presented as the domain of religion? The concept of this feeling would be Kant's contribution to a theory of religious feelings - especially since he presents a theory of feelings in the first book of the Critique of Judgement. However, this assumption is problematic in two respects. First, Kant is explicitly and extensively addressing feelings there but only aesthetic feelings. The feeling of beauty is described as disinterested delight, pleasure at the free play of reflection, a pleasure of reflection that has become independent. One can see an indirect answer to the question what may I hope in it, but not the feeling of hope itself. 'Beautiful things show that the human being fits into the world'11 - this early reflection can also be understood as the programme of the Analytic of the Beautiful. Hope is - not exclusively, but also - due to this indication that we fit into the world. But the feeling of beauty that provides this hope is not itself the feeling of hope. Neither is it a feeling called hope, nor is hope as an epistemic-practical attitude somehow topical in this feeling. The relationship between aesthetic feeling and hope is indirect: the aesthetic feeling contributes to strengthening trust in the world. The latter might contain the answer to the question of hope - it is an indication of what hope is directed at.

Second, it does not seem as if hope would count as a feeling at all for Kant. There are formulations like the following in the Critique of Judgement, where Kant talks about 'affections of hope, fear, joy, wrath, scorn. ${ }^{12}$ But the ordering of these feelings already shows that this is a conventional list from the perspective of the history of philosophy. The sentence has to be understood as a trace of the Stoic teachings to which Kant sometimes reacts in his work. Nor can hope be a candidate for the religious feeling, because affections and feelings are not the same for Kant. Affection is a raptus that completely captures the mood, Kant already

\footnotetext{
${ }^{9}$ See CpR.

${ }^{10} \mathrm{CJ}$, \$\$ 88-91.

11 ' $[\ldots]$ and that their intuition matches with the laws of intuition.' Immanuel Kant, Refl. 1820a, Akademie-Ausgabe Vol. XVI, p. 127.

${ }^{12} \mathrm{CJ}, \S 54$.
} 
noted in the 70s in his Anthropology from a Pragmatic Point of View. ${ }^{13}$ It does not have to do anything with the meaningfulness of feelings. No doubt a feeling is also a mood, but a mood that can be seen as a 'mental representation of a subjective state' (Roderich Barth). ${ }^{14}$

Kant mostly uses the term hope so that it could also be replaced by 'positive expectation', 'confident attitude' or 'a claim that is intuitively regarded as justified' or - as I would suggest - speculative reflection. With the analyses of reflective judgement in the third critique in mind, one can profitably reformulate the question 'What may I hope?' into 'What may I believe?' Then we can regard the ideas that constitute practical rational faith as the objects of hope, and we can arrive at the conception that hope may be accompanied by a feeling, and that it can articulate itself in a feeling, but that it is something different from a feeling. The speculative talk about more happiness, ${ }^{15}$ the 'hope for a future life, ${ }^{16}$ the 'hope of participating some day in happiness ${ }^{17}$ supports this interpretation just as much as the pragmatic talk about the hope [...] of achieving anything useful, ${ }^{18}$ or hope to succeed. ${ }^{19}$ 'For wherever quarrelling is permissible, there must be a hope of mutual reconciliation, ${ }^{20}$ Kant writes, for instance, and thus characterizes a potentially emotionless estimation. Belief is an epistemic attitude for Kant: subjectively taking something to be true. ${ }^{21}$ Likewise, hope is an epistemic-practical attitude that can be connected with a feeling. A manner of speaking such as 'This gives me a feeling of hope' is possible, according to this conception, but has to be understood as genitivus objectivus: as a feeling that belongs to hope like an attribute or element, and not as genitivus subjectivus: as a feeling that would be hope.

${ }^{13}$ Immanuel Kant, Anthropologie in pragmatischer Hinsicht (1798), AA Vol. VII, p. 253.

${ }^{14}$ Kant subsumes stirrings as distinct as affections and feelings under the greater concept of 'motion' as the inner movements of our mood. Cf. Anthropologie, p. 232.

${ }^{15}$ Immanuel Kant, Kritik der reinen Vernunft (1781/1787), AA III (henceforth: CPR), p. 424. In English: Critique of Pure Reason, trans. by J.M.D. Meiklejohn.

${ }^{16}$ CPR, p. 488; p. 492.

${ }_{17}$ CPR, p. 130.

${ }^{18}$ CPR, p. 548.

${ }^{19}$ CPR, p. 163.

${ }^{20} \mathrm{CJ}, \$ 56$.

21 'I had therefore to remove knowledge, in order to make room for belief' (CpR, p. 19). Whereas, according to Kant, I can only realize - i.e. know - what I can empirically prove, he also writes: 'I can think whatever I please, provided only I do not contradict myself.' (CpR, p. 17). For belief as a form of thinking the rule of freedom from contradictions applies, but not the restriction by the empiricism criterion. 
Now we cannot deny that the already mentioned 'hope for a future life, ${ }^{22}$ the 'hope of participating some day in happiness' ${ }^{23}$ belong to the motifs of religious belief. It is not by mere coincidence that these quotes are taken from the context of the doctrine of the highest good and the related doctrine of postulates. Here it is certainly true that these expectations go along with emotional stirrings. But for the reasons already mentioned, it would be problematic to understand them as 'the religious feeling'.

II.

Once again, and despite the cautious results so far: on the basis of Kant's critique of reason, one could easily talk about a religious feeling. There is an extensively analysed feeling caused by reason that is active in the centre of our rational self-conception. One would have to extrapolate from this feeling, I think, when wondering about the conception of religious feeling in Kant's philosophy. I am referring to the moral feeling of respect for the law that I mentioned in the beginning. Kant has fought hard to solve the problem of the motivation for acting in accordance with the moral law and the corresponding duty. In the Moral Mrongovius from 1770 he writes:

When I judge by reason that the action is morally good, much is still missing for me to undertake the action that I have so judged. But if this judgement moves me so that I undertake the action, then it is the moral feeling. Nobody can and will accept that the intellect can have a moving capacity, surely the intellect can judge, how this judgement could motivate so that it turns into an incentive, the will to undertake an action, to understand this is the philosopher's stone. ${ }^{24}$

The 'breakthrough of 1769 ' is not long ago at this point. One can clearly see that Kant is still directly influenced by Hume's conception of reason as a passive capacity. In the context of his own, early conception of reason, he is looking for a feeling that alone could motivate the practical implementation of knowledge or insights. In the first critical work on morals from 1785, this still has not changed:

\footnotetext{
${ }^{22}$ CPR, pp. 488, 492.

${ }^{23}$ CpR, p. 130.

${ }^{24}$ Immanuel Kant, Moral Mrongovius, AA Vol. 27/II, p. 1428.
} 
In order for a sensibly affected rational being to will that which reason alone prescribes, the 'ought', there obviously must belong to it a faculty of reason to instil a feeling of pleasure or satisfaction in the fulfilment of duty, hence a causality of reason to determine sensibility in accordance with its principles. ${ }^{25}$

After the conceptual overcoming of moral sensualism - which Kant had seriously considered until the mid-1760s in his search for the principle of morals, while being unsatisfied with the cognitivism of rationalistic German enlightenment ethics - he still sees a systematic role for feeling in morality that is systematically restricted, but also systematically validated. Feeling cannot constitute the foundation of morality, but it must be the motivation for acting upon what reason considers as a good action. Kant does not employ feelings as the justification of morality, but as moral motivation. His intransigence to only accept an 'incentive' for moral actions that stems from reason alone, without any empirical elements, now becomes more resolute while acknowledging the necessity of an emotional embedding of morals, and Kant also maintains it in his future work. He wants to solve the problem of motivation by postulating a feeling that moves us towards acting. The point is not solely to identify a feeling that might provide moral motivation. It also has to be a feeling that can be shown to be an effect of reason: a feeling self-effected by reason (GMM, p. 401) is the term that Kant will coin for it. Due to his methodological insistence that there must not be any heteronomous influences in the operation of reason, Kant, in his analysis of the incentive for pure practical reason, makes huge efforts to show how we should understand this feeling.

In the description of this feeling as the incentive of pure practical reason, it is first characterized on a purely formal level. This is supposed to strengthen the feeling's a priori character and adds the mechanical model of pressure and counterpressure through the picture of 'removing the counterpoise' to the characterization. Kant first formally claims that the moral law has a 'negative effect' on the senses: 'For all inclination and every sensible impulse is founded on feeling, and the negative effect produced on feeling (by the check on the inclinations) is itself

${ }^{25}$ Immanuel Kant, Grundlegung zur Metaphysik der Sitten (1785), AA Vol. IV (henceforth; GMM), p. 460. In English: Groundwork for the Metaphysics of Morals, trans. by Allen W. Wood. 
feeling. ${ }^{26}$ These effects of the moral law are due to its aim of bringing all inclinations under a generalizable maxim. By this restriction of potential determinants that could impede the influence of the moral law on the maxims of action, the path is also cleared for this influence:

For by the fact that the conception of the moral law deprives self-love of its influence, and self-conceit of its illusion, it lessens the obstacle to pure practical reason and produces the conception of the superiority of its objective law to the impulses of the sensibility; and thus, by removing the counterpoise, it gives relatively greater weight to the law in the judgement of reason (in the case of a will affected by the aforesaid impulses). (CpR, pp. 75f.)

'Thus', i.e. with regard to such a dialectics of reason's pure self-reference, Kant can determine respect for the law as an element in our awareness of the moral law - even as a necessary element: it is 'morality itself, subjectively considered as a motive' (CpR, p. 76).

This is supposed to illustrate the feeling's character of being caused by pure reason, i.e. being free from heteronomous elements. These elementary stipulations form the intelligible structure of the theory. If this was all, however, we would find it difficult that we are in fact talking about a feeling here. But on a different, a second, level, Kant also attempts to show the effects of the feeling. Being aware of the moral law, 'our pathologically affected self', through which 'our nature as sensible beings' makes its demands 'as if it constituted our entire self' ( $\mathrm{CpR}$, p. 74), is restrained. The permissive attitude towards our inclinations in self-love is restricted 'to the condition of agreement with this law' (CpR, p. 73). Self-conceit is 'indefinitely check[ed]' (CpR, p. 74). By restricting our inclinations, the moral law causes a feeling of 'unpleasantness' $(\mathrm{CpR}$, p. 75) and 'pain' (CpR, p. 74), hence a strong 'impression of displeasure' (CpR, p. 78). It humbles us 'in our self-consciousness' (CpR, p. 74), which at the same time quasi automatically causes - by a law of acknowledging what is stronger - a feeling of respect for the cause of the humiliation. This respect is also a 'positive feeling' as the 'humiliation on the sensible side, is an elevation of the moral, i.e., practical, esteem for the law itself on the intellectual side. The self in its supersensible existence - as a free person - partakes in this elevation (CpR, p. 79).

${ }^{26}$ CpR, pp. $72 \mathrm{f}$. 
The mortification of our self-love ( $\mathrm{CpR}, \mathrm{p}$. 74) corresponds to an elevation of our self-esteem due to the promotion of pure rational activity, i.e. admitting the law into the maxims. In the feeling of respect, the law restricts the pathologically affected self and sets the actual, rational self free.

The considerations at the end of Book I help us understand this feeling caused by reason and its affinity with religious consciousness: in the Critical Analytic of Pure Practical Reason, Kant reflects on the justification of the perspective from which the subject in the conscience of his supersensible existence' (CpR, p. 98) claims the 'transcendental freedom' of his actions (CpR, pp. 96f.). Here the reference to a guilty conscience due to actions the subject should rather have refrained from doing takes the role of a persuasive argument: a guilty conscience ex negativo indicates the existence of an awareness of responsibility for one's actions and thus freedom. In his description of 'that wonderful faculty in us which we call conscience' that is articulated in 'repentance for a long past action' as a 'painful feeling produced by the moral sentiment' (CpR, p. 98), Kant presents the form of respect for the law in a retrospective judgement. In the Groundwork, Kant had already mentioned 'selfcontempt and inner abhorrence' (GMM, p. 426) in the face of a bad action as a modification of respect in case of a deviation. So if we find it hard to imagine what respect for the law is supposed to be, the guilty conscience - due to its reflection on possible and 'long past' actions provides an illustration from everyday life. In the Metaphysics of Morals, Kant writes that 'pain' from 'remorse of conscience' is - in analogy to the feeling of respect - 'moral' in origin, but its effect is 'physical' (MM, p. 394). This constitutes a paraphrase of what he calls a feeling caused by reason in the Critique of Practical Reason. ${ }^{27}$

In my larger work on Kant, ${ }^{28} \mathrm{I}$ have tried to explain the inner structure of this moral feeling, the only legitimate incentive of pure practical reason, by the retrospective use of the analysis of the feeling of the sublime. In the feeling of the sublime, as analyzed in the Critique of Judgement, no pure pleasure is experienced as in the feeling of the beautiful. It is rather

${ }^{27}$ In Religion within the Boundaries, he will then write: 'Hence conscience might also be defined as follows: it is the moral faculty of judgment, passing judgment upon itself; only this definition would stand in great need of a prior elucidation of the concepts contained in it.' (REL, p. 186)

${ }^{28}$ Recki, Ästhetik der Sitten, see footnote 1. 
a mixed feeling. Unlike beauty, the sublime is not accommodating for the imagination. It is overwhelming for the imagination and by the way - due to the interplay of the free schematizing of aesthetic reflection - for the intellect. The object is too big for us to represent it in an act of intuition (the mathematically-sublime), or it is too menacing and violent for us to bear it in quiet contemplation (the dynamically-sublime). Kant describes the feeling of the sublime as the classic case of a fascination, being torn between two poles, as a mutual attraction and rejection. In terms of our faculties, Kant analyzes this dynamics of contradictions as the failure of imagination and intellect, a tremor that is compensated by a counter-move of our mood. This is done by reason, as the capacity to draw conclusions, the capacity to provide totality in thinking, 'filling in', so to say. In contrast to the reference to beauty, no playful reflection between imagination and intellect arises here, but an agonal reflection between imagination and reason that relates the unsolved impression to its totalizing ideas. Facing something of enormous size - like the starry sky - the subject relates the idea provided by imagination to the idea of infinite size. Facing an enormous superiority that shows the subject its own physical frailty - like the ocean in the grip of a thunderstorm - the subject relates to the idea of supersensible freedom. In this way, we are torn between awe and joy, between consternation and self-assurance, because in the face of an abysmal challenge for imagination, we become aware of 'a power of resistance of quite another kind' (CJ, p. 261), as Kant writes. About this resistance in realizing the supersensible aspect of our determination, which is caused by a threat and terror, Kant says: we have 'a feeling of our possessing a pure and self-sufficient reason.' ${ }^{29}$ This passage provides one of the formulations where feeling is described as a propositional attitude ('... that $p$ '). It thereby shows that the feeling described this way also has an epistemic function. Due to a sense impression, and in aesthetic distance, the subject experiences a dynamics of pleasure by displeasure that results from an elevation by humiliation. In experiencing the sublime, the subject is filled with an 'intellectual feeling' (CJ, p. 192). Its formal shape as a variant of the aesthetically reflecting judgement influenced by rational ideas sheds new light on the analysis of the moral feeling of respect. The effect of imagining an object on the subject having this experience can be described by 'a rapidly changing attraction and rejection' in the feeling of the sublime. Analogously,

${ }^{29}$ CJ, B 98, my emphasis. 
in the feeling of respect for the law, it is the simultaneous humiliation and elevation in the face of the moral law's sublimity. ${ }^{30}$

IV.

There is an often quoted formulation that describes this closeness between an aesthetically describable experience of the sublime and the effect of the moral law. It also contains a clear hint at a religious feeling:

Two things fill the mind with ever new and increasing admiration and awe, the oftener and the more steadily we reflect on them: the starry heavens above and the moral law within. [...] The former view of a countless multitude of worlds annihilates as it were my importance as an animal creature, which after it has been for a short time provided with vital power, one knows not how, must again give back the matter of which it was formed to the planet it inhabits (a mere speck in the universe). The second, on the contrary, infinitely elevates my worth as an intelligence by my personality [...]. (CpR, pp. 161f.)

Two aspects are important in the present discussion: first, in the dialectic of a mood between annihilation (the former view annihilates, as it were, my importance) and elevation (the second, on the contrary, infinitely elevates my worth), the feeling of the sublime is laid out. Two years later, Kant will analyze it in the Critique of Judgement. ${ }^{31}$ Second, Kant talks about admiration and awe here. When it is mentioned for the second time - 'But though admiration and respect may excite to inquiry [...]' - we associate it with the moral feeling of respect for the law that is analyzed in the chapter on motives. And we thus realize a new connotation in the notion of respect. Respect and awe are hardly the same. Awe is more than respect. Awe seems to designate the dimension of 'morals in reference to God' as the creator, legislator and judge.

This fits with a characterization that can already be found in the Groundwork, where the chapter on motivation from the Critique of Practical Reason is anticipated, albeit in shorter form: 'Authentically, respect is the representation of a worth that infringes on my self-love.

30 See John H. Zammito, The Genesis of Kant's 'Critique of Judgement' (Chicago: University of Chicago Press, 1992).

${ }^{31}$ It is also noteworthy that the starry sky is the only example for the 'mathematicallysublime, the feeling of inconceivable size. 
Thus it is something that is considered as an object neither of inclination nor of fear, even though it has something analogical to both at the same time. ${ }^{32}$ Neither inclination nor fear, although analogical to both: awe - for an object of thought that makes me feel the simultaneous humiliation and elevation of my self by its sublimity. Hence we can think of the religious feeling in Kant as the feeling of respect for the 'author of the world', whose causality is 'consistent with the moral law' (CJ, $₫ 87$ ). It would be the feeling of respect for God as the creator, legislator and judge of the world. Given the overwhelming size of its object, the feeling would take the shape of awe.

This result is confirmed and expanded in the analytic of the sublime in the third critique, where Kant explicitly discusses 'reverence for the sublime' (CJ, p. 264). In this specification of the doctrine of the sublime, the concept and theory of the religious feeling are also instances of the Copernican Revolution - i.e. of the methodological turn towards the subject of cognition, of thinking and experiencing, that characterizes Kant's transcendental idealism. In his aesthetic-ethical debut from 1764, Kant still stated: 'Sublime properties cause high regard. ${ }^{33}$ In the third critique, he specifies this characterisation by not only explaining the aesthetic feeling by the concept of respect (CJ, p. 257), but by also calling it awe in comparison to fear of God (CJ, p. 260) and religious humility (CJ, p. 264). After addressing natural phenomena, under the concept of the mathematically-sublime, that convey the idea of infinite size to the experiencing subject, ${ }^{34}$ beginning with $₫ 28$, Kant moves on to a variant of the sublime headed by the concept of the dynamic-sublime. This form of the sublime is found in the idea of a simply superior might: 'Bold, overhanging, and as it were threatening, rocks; clouds piled up in the sky, moving with lightning flashes and thunder peals; volcanoes in all their violence of destruction; hurricanes with their track of devastation; the boundless ocean in a state of tumult; the lofty waterfall of a mighty river, and such like; these exhibit our faculty of resistance as insignificantly small in comparison with their might. But the sight of them is the more

32 GMM, p. 401, note.

${ }^{33}$ Immanuel Kant, 'Beobachtungen über das Gefühl des Schönen und Erhabenen' (1764), Akademie-Ausgabe Vol. II, p. 211 (Observations on the feeling of the beautiful and sublime), my emphasis.

${ }^{34}$ The example for this is the starry sky Kant talked about in the conclusion of the second critique: 'If we call the sight of the starry heaven sublime [...]' (CJ, p. 270) 
attractive, the more fearful it is, provided only that we are in security.' (CJ $\$ 28$, p. 261)

Provided only that we are in security: this conditional is decisive for aesthetic reflection. Only the potentially destructive might that is primarily a natural object of fear is a candidate for the aesthetic feeling and judgement. But the aesthetic judgement and feeling are only possible in the face of this might if the subject is unaffected by this object's actual effects. Only when the terror is suspended while seeing the terrible can an aesthetic attitude towards the object arise. Concerning the exquisite objects of this aesthetic experience, the 'mountain peaks rearing themselves to heaven, deep chasms and streams raging therein, deep-shadowed solitudes that dispose one to melancholy meditations', etc., Kant in order to phenomenologically approach the feeling of the sublime also talks of astonishment that borders on terror, dread and holy awe (CJ, p. 269).

A side-product of the thought developed here is that it also provides a basis for an aesthetics of the religious. Given the character and size of the issue, it is not just coincidence that Kant talks about God when explaining the possibility of a terror suspended in distance:

Thus the virtuous man fears God without being afraid of Him; because to wish to resist Him and His commandments, he thinks is a case as to which he need not be anxious. But in every such case that he thinks as not impossible, he cognises Him as fearful. (CJ, pp. 260f., my emphasis)

The analogy has its limits (in the formal characterization of integrating fear and terror into the distance-requirement), since the fear of God is not an aesthetic feeling. But it is remarkable that, according to Kant, the aesthetic feeling of the sublime and the awe of God can be explained by reference to each other. Even the point of the 'subreption' (CJ, p. 257) that Kant develops in the analysis of the dynamic-sublime (the fact that the experiencing subject's own sublimity over the destructive superiority of nature is enjoyed in relishing awe, ${ }^{35}$ due to 'a kind of self-preservation', CJ, p. 261), has its correspondence in religious feeling. Kant uses the example of forces of nature - which are presented as the expression of divine anger and sublimity - to show that the mood of 'subjection,

${ }^{35}$ Kant talks about 'respect for our own destination, which by a certain subreption we attribute to an Object of nature (conversion of respect for the Idea of humanity in our own subject into respect for the Object)' here (CJ, p. 257). 
abasement, and a feeling of complete powerlessness' only seems to be the appropriate attitude in approaching the godhead. It is not true that 'prostration, adoration with bent head, with contrite, anxious demeanour and voice, seems to be the only fitting behaviour in presence of the Godhead' (CJ, p. 263).

Just as the enlightenment thinker will insist in his Religion within the Boundaries that the only reasonable form of fear of God and worship is a moral conduct of life, ${ }^{36}$ he already derives a similar use for the religious feeling from the analysis of the sublime: the mood that is 'far from being necessarily bound up with the Idea of the sublimity of a religion and its object' needs to be discarded.

The man who is actually afraid, because he finds reasons for fear in himself, whilst conscious by his culpable disposition of offending against a Might whose will is irresistible and at the same time just, is not in the frame of mind for admiring the divine greatness. For this a mood of calm contemplation and a quite free judgement are needed. Only if he is conscious of an upright disposition pleasing to God do those operations of might serve to awaken in him the Idea of the sublimity of this Being, for then he recognises in himself a sublimity of disposition conformable to His will; and thus he is raised above the fear of such operations of nature, which he no longer regards as outbursts of His wrath. (CJ, pp. 263f.)

Against the background of the correspondence between God's sublimity and the sublimity of practical rational belief, which justifies the counterpart sublimity of the rational human being, Kant dares to understand 'even humility, [as] a stern judgement upon his own self' and at the same time as a 'sublime state of mind consisting in a voluntary subjection of himself to the pain of remorse, in order that its causes may be gradually removed'. (CJ, p. 264) This explication of the religious attitude as an element of practical self-awareness can also help us understand that, according to Kant, in moral consciousness ('he could do this because he ought to') the human being realizes 'a depth of divine dispositions' that 'make him feel a holy awe given the size and sublimity of his true determination. ${ }^{37}$ The brief sketch of religious feeling in the third critique - where this is not at all the main subject - already leads into the centre of Kant's critique of reason: the awe of God implies awe of

${ }^{36}$ Kant, Religion within the Boundaries of Mere Reason.

${ }^{37}$ Immanuel Kant, 'Über den Gemeinspruch: Das mag in der Theorie richtig sein, taugt aber nicht für die Praxis', Akademie-Ausgabe, Vol. VIII, pp. 287f. 
one's own destination by 'dispositions' that allow us to fulfil the claim of reason which culminates in the idea of God.

The religious feeling we were looking for would thus be the feeling of awe that can be construed in the extrapolation of the feeling of respect for the law. The latter itself can be better understood in analogy to the feeling of the sublime.

Hence the thesis of my interpretation and extrapolation is: a characterization of the religious feeling in Kant's critiques of reason and their analyses of feelings is possible. It has to be understood in analogy to the feeling of respect for the law and thus to the feeling of the sublime. The religious feeling would, as certain formulations suggest, refer to awe of the inconceivable size of God. ${ }^{38}$ The religious feeling of awe would also be a feeling caused by reason - an instance of a judgement-based feeling. The respective judgement is a reflexive judgement, an achievement of the reflecting faculty of judgement. The religious feeling would obviously resemble Schleiermacher's 'plain feeling of dependence', but given the analogy with the dialectics of the sublime, it would also include the complementary component of self-elevation.

In the 'Analytic of the Sublime', Kant establishes an explicit connection between the concept of the sublime and the religious feeling:

Perhaps there is no sublimer passage in the Jewish Law than the command, Thou shalt not make to thyself any graven image, nor the likeness of anything [...]. This command alone can explain the enthusiasm that the Jewish people in their moral period felt for their religion, when they compared themselves with other peoples. (CJ, p. 27)

Acknowledgment. This paper was originally presented in Tübingen, Germany, in October 2013, at a conference for the Analytic Theology Project, generously funded by the John Templeton Foundation.

38 Compared to the mathematically-sublime, everything else seems small. The dynamically-sublime is the impression of something that is plainly powerful. Both would be integrated in this concept of the supreme being. 